\title{
The Evolution of the Frontier in the East- ern Caucasus and Cossack Lifestyle in the Region in the Eighteenth and Nineteenth Centuries
}

\section{Magomed M. Gasanov}

Dagestan State University

\begin{abstract}
Abidat A. Gazieva
Institute of History of Archeology and Ethnography of the Dagestan Federal Research Center of the Russian Academy of Sciences
\end{abstract}

\begin{abstract}
Basing on the analysis of a number of sources and literature survey, the present article traces social transformation of the Cossack subethnos as a service class and as the main controlling agent in the NorthEastern Caucasus. This study examines the application of the frontier theory and attempts at systematizing literature on the research subject. The work considers the concept of the southern frontier and examines its various components: economic, cultural and related to household, administrative and managerial. In this study, we have drawn parallels between the Cossack estate and various types of service classes known in the world history; this helps to even more clearly reveal the uniqueness of the Russian Cossack estate. We made an attempt of a systematic analysis of the role and importance of the Cossacks in the formation of the frontier in the south of the Russian Empire, as well as comprehensively considered which transformation the estate experienced during the eighteenth and nineteenth centuries. The article pays considerable attention to the relations between the Cossacks and highlanders, showing by various examples the mutual influence of cultures and traditions.
\end{abstract}

Keywords: Cossacks, highlanders, service class, frontier, culture, mutual influence.

Social Evolution \& History, Vol. 20 No. 2, September 2021 174-197

(C) 2021 'Uchitel' Publishing House

DOI: $10.30884 / \mathrm{seh} / 2021.02 .08$ 


\section{INTRODUCTION}

From the earliest times, the important military-strategic and tradeeconomic routes crossed the Caucasus territory; so this region has always been an arena of conflicting interests of great states. The Russian Empire used to be one of the major geopolitical players in the region and aspired to expand and defend its own southern borders. The most appropriate way to join and further involve the region in the allRussian political, economic, administrative and cultural environment was to build border fortifications in the south of the state.

The system of Russian border fortifications in the Caucasus played the key role in the development of relations between Russia and the Caucasus. A number of border fortifications built during the period from the sixteenth to the seventeenth centuries laid foundations for the construction of the Caucasian line based on the previously existing cordon sections along the Kuban, Malka and Terek rivers, merging them into a common strip of border fortifications. The initial purpose of the line was purely defensive but later its role expanded. The defensive function of the line was assigned to the Cossacks, who formed a sub-ethnic group in the region.

\section{DATA AND METHODS}

The primary information on the research topic is based on archival material from the Central State Administration (CSA) of the Republic of Dagestan, in open resources and in academic publications. Huge factual data were taken from monographs on different historical periods. All available literature and sources that formed the basis of the study were subject to critical analysis whenever possible. With respect to a number of sources and monographs (the end of the nineteenth the beginning of the twentieth centuries) and primary sources on the topic, one should note that they are characterized by subjectivity and descriptiveness, so one should apply the method of critical analysis when working with them. Using the theoretical and methodological basis, we have chosen the principles of objectivity and historicism. We applied historical-comparative, historical-situational, and sociocultural methods as the main research methods to comprehensively study various aspects of the Cossack material culture and their everyday mode of life and to trace their relations with neighboring peoples and to reveal the importance of an appropriate national policy towards local peoples. In theoretical terms, the main concept applied is the 
Great Frontier developed by Walter Prescott Webb (1964) who gave Turner's frontier thesis a broader understanding and expanded the geography of its application (Frederick Jackson Turner 2009, the founder of the frontier theory). Due to its multidimensional and complex character of the subject of the study, historiography tends towards an interdisciplinary approach. The main methods and principles of research are based on the problem-chronological and civilizational approaches. In our study we distinguish between 'colonization' and 'frontier' as structurally alternating but not synonymous concepts. In our understanding, colonization is a process, while the frontier is the final result which may fail to appear during colonization. We considered the creation of border fortifications in the Caucasus in the context of a frontier theory. The term 'frontier' is similar to the term 'borderline'. Although, today the notion of 'frontier' is used rather often in historical research, still the fundamental essence of this concept is limited to historical and geographical zone of economic and cultural relations between peoples belonging to different civilizations. The formation of the Russian multinational state has always been among the most significant issues for the Russian historical science. Defining the main directions of the study and application of frontier theory to the Caucasian policy of the eighteenthnineteenth centuries allows not only a more detailed study of the region's history, but also helps make predictions and update the regional policy, especially with respect to its national aspect. The frontier theory, which originated within the framework of the American historical school, allows us to examine the history of Cossack settlements in the Eastern Caucasus, as well as extrapolate aspects of modern cultural dialogue through the prism of the past historical events. The frontier theory can be examined with the help of various markers - the formation and transformation of forms of dialogue between cultures, the exchange of elements of material and spiritual values, including the matrimonial characteristics of the people.

Within the context of the frontier theory, the essential mechanism of the formation of multiethnic basis in the southern region of Russia can be regarded as the basis of the historical and ideological basis of the state.

When considering and applying the frontier theory, it is also important to apply it within holistic political, socio-economic, geographical approaches, and also take into account the peculiarities of social thinking and cognitive processes typical of ethnic groups of the frontier. The frontier theory, which takes into account the multidimensional 
character of historical processes and human existence, allows us to consider history not only from the socio-economic perspective but in a comprehensive manner. The term frontier was introduced into Russian scientific discourse from the English language; there is no exact translation of this term. We cannot say that the frontier is a border, because this concept (border) is specific and fixed. In the most general sense, we can say that this is a border zone, or a contact zone. The legal establishment of the border is a one-time act in the process of colonizing the territory, while the frontier is an area of the political landscape with a peculiar type of evolution of socio-economic, administrative, and cultural relations. There exist many interpretations of the frontier concept. In understanding the phenomenon of the frontier, we hold the position of the following foreign and Russian authors: Thomas M. Barrett (2000), Michael Khadarkovsky (2019), Marina Ryblova, and Sergey Panarin (1999).

\section{DISCUSSION}

The Cossacks' history goes back to the ancient times. Today, the Cossacks are 'one of the actors of a complex and controversial process of the formation of the North Caucasus historical and cultural community' (Garunova 2008: 91). From the moment of their coming to the North Caucasus, Cossacks began to play a significant role in the history of the region. Mistakenly, some researchers sometimes oppose the Highlanders and the Cossacks, since the distinction between them is very arbitrary. While participating in the genetic, political, economic, cultural and everyday history of the region, the Cossacks adopted the everyday culture of the peoples of the North-East Caucasus. The Terek Cossacks consisted of the representatives of various ethnic groups, they can be considered as a result of ethnic diversity and synthesis. This diversity was caused by the fact that representatives of various ethnic groups and confessions joined the Cossacks. This is evidenced, for example, by Vasily Potto who spoke in his studies about the ethnic composition of the Terek Cossacks, characterizing them in the following way: 'Significant groups of Orthodox Ossetians and Cherkasy, as well as Georgians and Armenians, who fled from Ottoman and Persian oppression, were accepted into the Cossacks'. ${ }^{1}$ Living in the close proximity to the indigenous population of the region, the migrants interacted with a foreign ethnic environment, which could not but affect the Terek Cossacks' family life, everyday culture, appearance and character (Bulatov and Bolokhina 2010: 106). Adopting some traditions, 
customs, and housekeeping methods from the neighboring peoples, the Cossacks formed their own peculiar economic way of life. It should be noted that the Cossacks acted very tolerantly and receptively towards the culture of indigenous peoples.

While in the sixteenth-seventeenth centuries, the borrowings within the Caucasian frontier were hardly noticeable, due to the fact that relations and connections were at the stage of inception, then in the eighteenth-nineteenth centuries the mutual influence became obvious. Basically, borrowings could be traced in the household sphere. The highlanders borrowed from the Cossacks and settlers new forms of land cultivation, new varieties of cultivation of agricultural crops.

Speaking about the frontier, it should be noted that it is not the landscape that is fundamental for its emergence and formation, but the types of social construction of reality and the formed mental type resulting from assimilation of ethnocultural groups.

We agree with the point of view that the frontier is 'a zone of intercultural (civilizational) interaction outside clearly defined and recognized state borders ... evolved in different historical periods'. ${ }^{2}$ The frontier should be perceived as a boundary which is spatially not fixed (i.e., it is blurred and movable).

Employing the frontier theory, this article makes an attempt to describe the Russian presence in the Caucasus not from the position of force, capture and resistance, but as the formation of a border zone where the cultures of the mountaineers, Cossacks and migrants were mixed. In this respect, we are close to the position of Thomas M. Barrett (2000) who argues that it is impossible to consider the Caucasian policy in the context of colonialism, this is precisely the frontier, since the tsarist administration did not set the goal of making the region a raw material base for the empire, but on the contrary, tried in every possible way to involve it in a single economic space of the empire. In the area of the Caucasian line, there were formed different types of frontier, including economic and cultural.

The formation of the economic frontier became the most significant for the Russian administration in the region. The tsarist administration was aware of the importance and significance of trade with the highlanders. In particular, in 1818 Aleksej Petrovich Ermolov wrote to Count Guryev, 'Trade is the only means of rapprochement with the mountain peoples, a means that can subsequently deliver the greatest benefits ...' (Barrett 2000: 48). A similar point of view was expressed by Lieutenant General of the Left Wing of the Caucasian 
Line Nikolaj Evdokimov. Speaking of the importance of the settlements of peaceful mountaineers along the Caucasian line, he emphasized that 'improving their life out of necessity, the mountaineers bring us very important benefits. The auls [mountain village in the Caucasus and Central Asia], settled in front of our lines, defend themselves, of which we see daily examples, reducing a significant need for troops' (Velikaya 2012a: 52). In the same passage, Evdokimov speaks of the need to build a certain model of relations with the peaceful highlanders,

I am convinced that disarming of the Caucasian highlanders can be achieved without any harm for us only with the temporary success of our weapons and the gradual development of administrative measures tending to introduce commercial and industrial inclinations among them, accustoming to the great comforts of life. Removing the natives from the theater of war, on the occasion of our movement forward, gradually consolidating his well-being and attracting other disobedient ones to ourselves, we at the same time associate their benefits with ours, and there is no doubt that a highlander, once taking up trade or another industry, congenital greed, for the sake of benefits, will forget about the weapon (cited in Velikaya 2012a: 52-53).

In order to involve the highlanders into trade with Russia, Alexander I by decree of July 6,1810 'ordered to expand the exchange trade with the highlanders along the entire Caucasian line'. ${ }^{3}$

Highlanders, bringing agricultural and handicraft products to $\mathrm{Ki}$ zlyar, bought all kinds of goods from Russian and European manufactures here. From the archival materials of the Central State Archive of the Dagestan Republic on 'information for compiling Russian statistics, collected on the affairs of the Kizlyar customs,' it is clear that in 1828 , the goods were imported from mountain possessions to Kizlyar at the amount of 140,950 rubles, and exported from Kizlyar to mountain possessions - at the amount of 115,965 rubles, in the internal Russian provinces - at the amount of 526,470 rubles (Velikaya $2012 b$ ), which indicates the involvement of the region in the allRussian economic space.

The above data also testify the advancement of the Kizlyar markets to a higher level of market relations since they got involved in international trade; and this would change the economic thinking of 
the population. Speaking about the variety of products presented on the Kizlyar markets, many researchers pointed out that representatives of different nationalities would come to sell goods there, which contributed to the integration of the region population. In the markets one could meet 'Lezgins selling honey, Chechens offering customers knives and daggers, Cossacks and Cossacks ... to hear the dialects and dialects of the entire Caucasus!' (Central State Archives of the Republic of Dagestan, Fund.374, Inventory.1, Business.137)

The region developed a clear production and labor specialization, beneficial to all peoples living here. Yliodor Shidlovsky in 1842 visited the Kizlyar bazaar and left information that on the market one could see

a Lezgin with copper dishes, a cyst and a Chechen with guns and sabers. The Kostekovsky Kumyk brought firewood and tarkals, the Aksayite laid out the skins and sheep's wool, the Armenians and Georgians offered you berries, vegetables and fruits. And there, closer to the Terek, ruddy Cossacks from Dubovskaya, Chervlyonnaya, Naurskaya and other Terek villages, sit on carts laden with watermelons, melons, cucumbers, beets, cabbage, etc. (Pylkov 2011).

Gradually, by the first half of the nineteenth century, Russian money began to play an increasingly significant role in trade. Money turned out to be in great demand among a wide variety of peoples, especially Russian rubles which drove out barter trade. Trade relations were also facilitated by the decree of the Russian emperor which stated '.. to establish currency exchange points in the city of Kizlyar, as well as throughout Russia' (Shidlovsky 1843: 64).

This imperial decree made closer the trade relations between Kizlyar and Russian provinces. Trade with Russia left a noticeable imprint on the occupations of the mountain population, it promoted the growth of production and specialization of a number of branches of the mountain economy so that many crafts and trades obtained commercial value. More and more agricultural and other products were sold. Not only the economy changed but also the Dagestanis way of life.

The development of commodity-money relations contributed to overcoming the subsistence economy of inhabitants of the region. Trade relations periodically ceased under the influence of military events within the territory of the Caucasian Line, but both the Cossacks and the mountaineers were interested in expanding trade. 
During its formation, the territory of the Caucasian frontier witnessed a constant exchange of knowledge, skills, and abilities among representatives of various ethnic groups living within its borders. Thus, the Russian settlers borrowed from their neighbors - Kumyks, Kabardians, and Chechens - sericulture, viticulture, madder growing, as well as the technique of growing these crops.

This led to the emergence of many foreign words in the language of the Russian inhabitants of Dagestan. Thus, in the dialect of the inhabitants of the capital of Alexandria, the Kizlyar region, there are many words denoting tools borrowed from the Kumyk language. This is indicated by Asker Selimov who writes that, 'The main tools in the agricultural economy of the Kumyks were the saban (heavy plow), balbu (threshing boards), orak (sickle), chalgy (scythe), kazgir (iron shovel of local work)' (Selimov 1964: 102). Many of these instruments, together with their names, were borrowed by the Russian neighbors. It is known that the dwelling is to a greater extent, than other elements of material culture, influenced by geographic environment which defines materials, construction techniques and forms. In the nineteenth century, when settling in new places the Russian settlers, especially pioneers, built their dwellings according to their traditional and familiar patterns.

Over time, under the influence of new conditions, '... a type of dwelling was developed that generalized the building traditions of various regions of Russia, experienced the influence of local building traditions and maximally responded to the natural-geographical and economic characteristics of the region' (Luguev and Mansurov 2002: 552). Among the settlers, both men and women, mountain charyks (one of the most ancient types of highlanders' footwear) became widespread. By the end of the nineteenth century, both Cossack male and female clothing had much in common with the mountaineers' clothing.

Note that the mutual influence of local and settlers' cultures proceeded in two directions: the Russian settlers adopted everything valuable and rational from traditional everyday culture of the Dagestan mountaineers and also assimilated their knowledge and skills that could facilitate adaptation to new living conditions.

The influence of Russian culture and life can be traced in the use by the indigenous population of Dagestan of the Russians' advanced experience of agriculture and cattle breeding, in learning the spiritual values of the Russian people, enriching them, in turn, by introducing their nationally determined features of spiritual life. The territory of 
the frontier was a place where, simultaneously with war, peaceful life was in full swing in all its manifestations (active trade contributed to the emergence of elements of the material culture of central Russia among the mountaineers, marriages were contracted, and consequently there was observed ethnic intermingling, etc.).

In the nineteenth century, capitalist relations were gradually established in the Russian Empire. This trend found its expression in the relationship between the Cossacks and highlanders in adopting forms of production. Due to economic necessity, the attitude of the Cossacks to land tenure forms and handicraft production changed, which ultimately led to similar changes among the highlanders.

In the process of interaction some elements of material culture, such as clothing and house decoration (household utensils) became similar among the Cossacks and mountaineers. The clothes of the Cossack became close to the clothing of a mountaineer, which was partly due to cultural and trade contacts. Besides, this clothing was comfortable during military activities. Due to the development of trade relations in the region, the highlanders discovered a variety of garden crops, as well as various goods, both Russian and foreign, that improved and formed the basis of their everyday relations. In addition, the highlanders were involved in the all-Russian market, which provided new economic opportunities for them.

The Cossacks and the highlanders also had similar attitude to family and marriage and division of household duties among family members. The mentality, material culture, as well as elements of spiritual culture were similar among the Cossacks and the highlanders, which fact may be explained by the tradition of centuries-old neighborhood.

John Berry and Rudolf Kalin elaborated the theory of a direct correlation between geographical mobility and ethnic tolerance, that is, a more mobile society in a geographical space is more open to connections with other groups and susceptible to their cultures (Lebedeva 1991: 121). Initially, the specific living conditions of the nascent Cossacks left a mark on the development of their sub-ethnos and had a significant impact on its ethnogenesis and on the relations between Cossacks and highlanders. The Cossacks would settle the territory of the Caucasus by flows that were uneven in quantitative, sexual and age respects. Initially, 'the waves' of predominantly males went to the Terek region. 'The Russian Cossack freemen on the Terek and partly on the Don for the first time kidnapped wives from the Caucasus' 
(Shcherbina 1910: 337). In the sixteenth and seventeenth centuries, there were many interethnic marriages, and even in the nineteenth century, when relations between Cossacks and highlanders were seriously aggravated, the Greben Cossacks had wives from Dagestan, Kabardin and Chechen peoples (Tkachev 1912: 87).

There were cases when the Cossack children returned to the villages after many years of captivity. Living in the mountains at a very young age, they adopted highland etiquette and mentality, and after finding their Cossack relatives, they remained in Cossack villages and would bring the mountain flavor into the traditional Cossack life.

The researcher Fedor Shcherbina cites the following data, 'in 1840, the Cossack woman of the Yekaterinodar village, Anna Shevchenko, recognized her son Lavrentiy in a Circassian Mustafa who had fled from the mountains by family traits and a burn on the leg. He was kidnapped as a small child and hardly realized that he was actually from a Cossack family' (Shcherbina 1992: 527-528).

The Terek and Greben Cossacks had the closest ties with the southern peoples of the empire. As a result of many years (of mostly peaceful) neighborhood with the highlanders, among the married Cossacks there were many women of local highland origin, especially Chechen, Kabardian and Nogais women (Kiryukhin 2000: 194). As Ivan Popko notes, 'the Cossacks soon acquired friendly and even family ties with the highlanders ... from whom they took grain bread, cattle, horses and even unmarried women for marriage' (Popko 1880: 24).

Researcher Oksana Mutieva indicates that, 'before the eighteenth century there were no special obstacles for mixed marriages' (Mutieva 2006: 35) and the Cossacks quickly adopted Caucasian customs: they began to either kidnapped brides for themselves, or get them as wives under an agreement with their parents (with the necessary payment of kalym).

But since the kalym was often too large for an ordinary Cossack (according to Peter Pallas, at the end of the eighteenth century it was 'often more than 1,000 guldens' (Pallas 1974: 214) the most frequent way to get a bride was 'abduction', i.e. bridal kidnapping which was however, widespread in the Caucasus (for the same reasons) (Omelchenko 1991: 62).

The description of cases of bridal kidnapping in the Caucasus region are found in the works of many authors. Thus, the researcher Natalia Velikaya indicates that, 'the Greben Cossack Frolov kidnapped 
Taymazova, the daughter of the Kabardian prince, and married her' (Velikaya 2004: 111).

There were cases when Cossack women became the wives of Caucasian mountaineers, mainly after being abducted. The girls were usually driven away in childhood, they were brought up in a mountainous environment and culture, so when they became adults, they often did not want to return to their home village, even if there was an opportunity. (Tsibulnikova 2008). Probably, this was due to the fact that by the time when the opportunity was provided, girls had already acquired families and the mountain mentality became native to them.

It should be noted that the basis of both the Cossacks and the mountainous environment in most marriages were arranged via bridal kidnapping. Back in the sixteenth century, during the period of their migration to the south, the Cossacks took wives from the regional ethnic groups since it was mainly men who moved and stayed in the region for a long period.

It should be noted that in any border zone (frontier) the cases of multi-ethnic marriages as a result of polyethnicity, are observed, even if the ethnic groups were in a state of enmity with each other. Thus, similar to the Cossacks, on the American frontier there were frequent cases of marriage between white settlers and Indian women that led to intermingling of their cultures and modes of live.

The Cossack sub-ethnos was characterized by a kind of synthesis of cultural environment, which implied unification of different cultures, traditions and characteristics of various ethnic groups. This was caused by the fact that at their origin and at the stages of their development, various ethnic groups and confessions were accepted into the Cossacks. As a result, the Cossacks became tolerant towards polyethnicity and polyconfessionalism. By means of such marriages, a type of Cossacks was formed with a peculiar domestic and behavioral culture (Archive of SONIA, Fund of Professor Kokiev. Inventory.1, Business. 203). The village life of the Terek Cossack Army also demonstrates similarity not only of the mental and cultural-everyday life, but also the external similarity between the Cossacks and highlanders, indicating that the Cossacks had 'dark-gray hair with black shiny eyes, or black hair and blue eyes; typical features of a Chechen are mixed with a high-born type of Nogai or Kalmyk, a mountain gait, harmony and flexibility are noticeable ...' (Statistical monograph ... 1881: 234). The performance of military service for many decades determined the life of the Terek Cossacks. Every Cossack regiment was also a site for 
economic development of the frontier with its villages, arable land, grazing land, roads, its own guard and police service, and administrative and economic management bodies. In the Kizlyar region, Cossack villages were connected by a cordon line with guard posts located in 1-2 kilometers from each other. It was the Cossack duty to serve at the posts, repair roads, build bridges, support fortifications, harvest timber for construction, and carry out land work.

A Cossack woman did all the housework and raised children. She got up with the first rays of the sun and ended all her household chores only after midnight. A Cossack man spent most of the time in the training camp. Dmitriy Vasiliev points out that 'numerous other services and duties exhausted all the forces of an ordinary Cossack and almost completely torn him from household economy, which fell on the woman's shoulders' (Vasiliev 1986: 155). The Terek Cossacks are representatives of the peoples of the North Caucasus, whose life is based on the family relations. In the second half of the nineteenth century, Cossacks lived in small families. They appreciated family life. In family relations a Cossack man considered his wife as the subject of his enrichment and they were 'almost equal in their rights' (Nomikosov 1884: 157), as indicated by a number of household features of the lifestyle of the Cossack villages.

The way of life of the goryanka, (a girl or a woman who lives in highlands) about which Ivan Kostemerevsky wrote that, '... they do not notice their situation and lead their ordinary life, they are still cheerful, laughing and singing in the midst of the most difficult work' (Zubov 1833: 80) was similar to the way of life of the Cossack women. The Cossack woman took care of her family, did a lot of work about the house and endured fatigue.

In the eighteenth century, the Cossack man was not engaged in housekeeping at all but by the mid-nineteenth century he gradually started to be involved in the family life. At first, the Cossacks were not serious about farming. They argued that farming was not an occupation for a man, since until the mid-nineteenth century they were engaged in military operations. Due to a similar attitude to everyday issues, agriculture was extensive among the Cossacks. The midnineteenth century sources point out that the Greben and Terek Cossacks were 'neglectful in farming' and that 'they produce very little grain (Zubov 1833: 104). All mentioned above also characterizes the principles of economic activity of the Cossacks, Leo Tolstoy writes, 'The Cossack spent most of his time on campaigns, hunting, or fish- 
ing,' and had '... a love of freedom, idleness, robbery, and war' (Tolstoy 1963: 18). Tolstoy very vividly and figuratively described the Greben Cossacks, describing them as a courageous tribe, related to the local population, but who '.. preserved the Russian language and the old faith in all their former purity' (Tolstoy 1963: 18). Since the midnineteenth century, the socio-economic situation in Russia changed, as a result of which the economic way of life in Cossack settlements was transformed. On the whole, the development of capitalist relations significantly changed the life of Russian society. A man begins to play an important role in housekeeping. The fact is that 'in connection with the increasing number of Cossack communities there was an increasing need for food supplies'. ${ }^{5}$ Cossacks began to lead a settled way of life, and, consequently, started to engage in agriculture. In addition, the fact that the Caucasian war was coming to an end contributed to increasing involvement of the Cossack man in housekeeping. This is also confirmed by the fact that after 1856 the term of military service of the Cossacks was reduced from 30 to 25 years, including 22-year field service and three years of internal service (Savchenko 1999: 25). The Terek Cossacks changed the foundations of economic activity, as 'their paramilitary life was a thing of the past' (Garunova 2008: 99). The combination of socio-economic transformations of the country's economic mode and political situation in the region contributed to the change of the way of life. In the mid-nineteenth century, in the Cossack household life there was a division of labor into male and female jobs. This can be judged with certainty, relying on one of the proverbs from Cossack folklore, which says, 'Without a master, a yard cries and without a mistress, a hut cries' (Mutieva 2006: 82). It shows that the male Cossack played an important role in housekeeping and he was also engaged in hard work outside the house. The Cossack man was responsible for cattle breeding, stocking up firewood, and harvesting hay. It is worth noting that in the Cossack villages of the Kizlyar region the development of cattle breeding was hindered by 'natural and random causes' (Materials for statistics ... 1868: 236) which included the protracted war, as well as the natural restrictions in the form of huge numbers of mosquitoes. From the statistical data of the second half of the nineteenth century it is clear that 'the tillage is the main concern of the Cossack master (head of the household)' (Ibid.: 228). Most of the Cossacks were engaged in farming in their regiments; the smallest part of them does not plow because of the lack of working cattle and equipment (Ibid.: 228). Land cultivation among the Cos- 
sacks was carried out by obsolete tools, without using equipment. Such a lag in the land cultivation methods could be explained by the fact that the population did not have a proper education, and they used traditional forms of land cultivation. 'In this matter, as in all other good deeds, a good education serves as a loyal assistant. It can break the long-standing order of things and bring great benefit to society' (Ibid.: 229). In the second half of the nineteenth century, Cossacks were actively engaged in gardening and horticulture. They planted various trees: pears, apple trees, cherry plums, plums, peaches, and cherries' (Ibid.: 234) but horticulture did not bring stable income since the gardens did not receive proper care due to the above-mentioned lack of fundamental knowledge. From statistical materials it can be seen that gardening was more developed than cultivated crops such as 'cucumbers, watermelons, melons, pumpkins, cabbage and others' (Ibid.: 234); the crop would satisfy their own needs and its part would be sold. The female duties also included work in the garden and in the field. Women did not mow while 'all other works were performed on a par with a man' (Mutieva 2006: 82). A similar principle of division of labor was common among the Dagestan highlanders; so one may speak about similarity between everyday traditions of the highlanders and Cossacks.

Since the mid-nineteenth century, there was observed an increasing involvement of male Cossacks in everyday life. However, it should be noted that until the mid-nineteenth century women still played a key role in household life while male Cossacks only started to participate in it. During the spring-autumn field work, women were usually occupied by domestic cares and, therefore, physically did not have time for children.

Except for the holidays, she works every day: public village work (digging canals, draining the water, strengthening the banks of the river, building gates, bridges, etc.), or her own household chores (vineyards, vegetable gardens, hayfields, reaping, thrashing) ... Children remain in the care of elderly people or elder brothers and sisters. In summer, at the opening of field work, mother leaves for several weeks in the field and does not see her children. So, she takes the infant with her (Materials for statistics ... 1868: 227).

Since there were many children in Cossack families, the older girls were usually nannies for younger sisters and brothers (Mutieva 2006: 
81). The life of a Cossack woman was strictly planned by doing various kinds of heavy chores; of course, it is similar to the life of a goryanka (a girl or a woman who lives in the highlands), who was also involved in numerous works from morning till late at night. Children worked along with women and men. Children in Cossack families from a very early age (from 5-6 years) were taught to work. Boys helped father in the yard and in the field, and girls helped mothers at home. Cossacks tried to attach their children to literacy. Cossacks tried to involve all members of the family in all matters, regardless of gender and age. 'For all regimental schools, the program was approved along with the provision on the army in 1845, it included: the law of God, grammar, arithmetic, calligraphy, and drawing' (Materials for statistics ... 1868: 243). It should be noted that only boys studied reading and writing, as the available data indicate that 'there are no schools for girls' (Ibid.: 244). Among the Cossacks, professing the Old Believers, girls received home education (Church Slavonic letter) in order to "have their own canon recital for deceased relatives. Bad word order who are not married' (Ibid.: 244). As some researchers indicate, the life and customs of the Cossacks are very similar to the general Caucasian ones, 'The mindset of the Terek Cossacks, considered to be part of the Russian people, was close to the way of thinking of the North Caucasus peoples' (Garunova 2008: 73). All mentioned above points to the process of rapprochement between the Cossacks and the highlanders. Speaking about the influence of the highlanders on the Cossacks' way of life, Potto noted that 'the Cossacks soon borrowed ... not only military habit and tactics, but adopted their weapons, landing and even clothing' (Potto 1885: 101). This fact is also supported by the fact that Cossack clothes and houses were a mixture of Russian and mountain cultural traditions. For example, according to Gerhard Miller, in the clothes of the eighteenth-century Terek Cossacks one may observe such an element of Russian culture as a quilted dress of rough fabric without sleeves or short sleeves to the elbow ${ }^{6}$ which was similar with a suit of goryanka. From the costumes of the goryanka, the Terek Cossacks adopted long dresses to the floor, various jewelry made of gold and silver.

The frontier theory is applicable to the Serbian Cossacks (they were called Granichars) which, similar to the Cossacks, represented a militarized social community (since the Cossacks included representatives from different classes) that defended the borders of the Habsburg Empire. As in the case of the Cossacks, the Granichars were at the 
state service and performed protective functions and were exempted from a number of duties. The border settlement included trench-forts, fortresses and small towns - villages, similar to the settlement of Cossacks in the villages, and cordon fortresses. Militarized life, joint security, differentiation of household duties - all these features indicate the similarity of the Granichars with the Cossacks. Both the Granichars and the Cossacks had been involved in the military service for many centuries and had formed as a professional military unit. In both cases, we may speak about the formation of a frontier zone, regional socioeconomic systems in the places where the cordon lines of the Cossacks and the Granichars were built. At the same time, we can confidently assert that the Cossacks are a phenomenon on a historical scale, since not any other militarized community (Granichars, the Stratioti, haydamaks, etc., with the exception of samurai since the samurai spirit was preserved in culture) has survived to this day. The Cossacks managed to preserve their material and spiritual culture under the influence of socio-cultural and economic transformations.

A mix of cultures was manifested in the construction and decoration of the houses of the Terek Cossacks. They were called huts and were usually made of brushwood covered with clay. Huts were built with the help of neighbors and relatives. Mutual assistance has always been an important element of the Cossack culture. By the end of the nineteenth century, the Cossack houses were still preserved on the Terek without a foundation and basement and with a clay floor.

The most common was flat wattle and daub roof. There were two and three-pitched roofs. By the end of the nineteenth century, the form and material of the roof and the way it was constructed underwent some changes. For the log houses which had a four-pitched roof, they started to use iron for roofs. The old methods of covering roofs with adobe (made of straw and clay) also changed - now they began to lay adobe in two rows, as it was spread in Central Russia. Wealthy Cossacks tiled their houses. Houses made of brushwood covered with clay were still covered with reeds or straw. There were usually two rooms in the hut: in the small one there was a stove, long wooden benches, and a table; in a large - wardrobe, a chest of drawers, and chests. The interior of the house was a bit similar to Russian houses. About the interior decoration of the Cossack houses Mr. Miller wrote that

[they] ... adorn the canopy with old images; ... there are no closets and they make wide benches, which, according to 
the Asian (style) habit, like clothes, are very low, in comfortable beds and pillows, on which pillowcases made from different silk materials and rags are sewn and put on staggered with checkered colors, and on those chests and chests become benches. In the hallway, along the walls, zbruzakazachskaya, squeaked with chops, sabers, checkers, darts of mutton, saddles. ${ }^{4}$

The style of interior of the houses was preserved over the eighteenth-nineteenth centuries. The occupation of the Cossack villages by the highlanders led to a large rapprochement between the Cossacks and their neighbors which gave 'a peculiar flavor, especially in the way of life, in rites, in songs and dances' (Maksimov 1890: 13).

In almost every house there was a spinning wheel, since the fabrics and clothes were homemade. Similar to other peoples of Russia, in the Cossack house part of the room was occupied by a wood-stove. In the same room, some cooking utensils were stored. Cossacks did their best to decorate their houses, so they put the most beautiful dishes in a prominent place of the house. The rest of dishes were placed under the shelves with the supplies; also there were additional kitchen utensils, barrels, vessels, and jugs.

Cups, wooden spoons and ladles were hung on the wall. In all houses there lay carpets on the floor, which were either homemade or exchanged for something with the highlanders.

It should be noted that the policy pursued by the tsarist administration regarding the Cossacks also determined their way of life. The Cossack communities were in a privileged position, which largely determined their living arrangements.

The fact that in 1817, due to the spill of the Terek, the settlements of the Cossacks were devastated, the economy fell into disrepair, 'the emperor, rewarding the losses they suffered, contributed Alexey Ermolov "fairly significant amounts of money"' (in Fyodorov 1991: 296). Also, creating favorable living conditions for the Cossacks, the tsarist administration made concessions to them in matters of administrative structure.

As Nikolay Vinnikov noted, 'in 1845 , a special provision was promulgated for the Caucasian Linear Army that separated the Caucasus region into civil and military management'(Vinnikov 1897: 163). Another fact indicating that the authorities favored the Cossacks, was that the Cossacks who were under the control of the military, 'were 
allowed to deal with cases of litigation on the basis of their former customs under the supervision of officials especially designated for this purpose; subject to criminal court martial law'.

Throughout the hostilities of the Caucasian War, the tsarist administration supported the Cossacks and was actively engaged in the Cossack colonization of the North Caucasus, considering Cossacks as a reliable support for autocracy in the Caucasus region.

The leitmotif of the Cossacks' resettlement policy in the Kizlyar region is an excerpt from the emperor's speech to the army in the Caucasus (cited in the monograph by George Tkachev), '... You are Russian Christian warriors; you prove to enemies that we are fierce on the battlefields, but that a civilian can find faithful cover and everlasting protection among our camp' (Tkachev 1911: 81).

During the Caucasian War, the tsarist administration pursued a consistent and deliberate policy in the region in order to attract the warlike mountaineers to its side with various levers of pressure, adapt them to the Russian mentality and everyday life, and by means of good neighborliness and 'multinational coexistence,' which was typical for Caucasus, this was easier to achieve.

\section{CONCLUSION}

As a result of our research, we have come to the following conclusions.

The culture and life of the Terek Cossacks and mountain peoples are closely intertwined over the centuries-old history of living together in the region. The rapprochement of the Cossacks with their neighbors and the tendency toward acculturation gave each of them peculiar features manifested in the way of life, rituals, and songs. It was a kind of synthesis of the actual Cossack and mountain lifestyle. During the Caucasian War, a peculiar way of life of the Terek Cossacks was formed, which was largely shaped by the pursuit of a consistent policy of Russia in the Caucasus, as well as a number of domestic factors. The tsarist administration used the 'divide and conquer' strategies in the region, thereby demonstrating the advantageous position of supporters of the Russian government. Cossack traditions in everyday life, their beliefs, clothing, which were formed in the late eighteenth early nineteenth centuries, have been preserved up to the present. Cossacks are a bright sub-ethnos in the history of our country. Despite the fact that the strongholds were built during the Caucasian War, later they became contact zones between the two warring parties. The Cos- 
sacks' culture, way of life, and living arrangements in the North-East and the Eastern Caucasus were largely determined by their contacts with the highlanders, which contributed to the rapprochement of peoples and further establishment of friendly relations in the region. Due to the creation of frontier zones and fortifications, multicomponent territories, including culture, economics, politics, the Russian Empire solved a number of geopolitical tasks in the North Caucasus: the expansion and strengthening of its southern borders, establishment of an administrative-political system and reliable control over it with the help of local peoples. In addition, during the hostilities there was a process of transformation of the everyday culture of the contact population of the frontier zones, which was caused both by a decline in military tension in the region, and by socio-economic trends for the development and expansion of capitalism throughout the empire. The lifestyle that arose in the contact zone subsequently began to spread to other parts of the region, which produced considerable effect on all sectors of economy and all spheres of life.

\section{NOTES}

${ }^{1}$ The history of the Terek Cossacks. The electronic library 'Entries'. URL: http://www/vehi.net/.istorya/potto/kavkaz/11/html (Электронная библиотека «Вехи».)

2 Markedonov S. South Caucasus: a polygon of interests. URL: Copyright@1999-2007. Political News Agency (Маркедонов С. Южный Кавказ: многоугольник интересов. URL: Copyright@1999-2007. Агентство политических новостей).

${ }^{3}$ Left Wing of the Caucasian Line (Tersk Region). Caspian region (Dagestan region) and Lezginskaya cordon line. Rare Book Fund IIFE DPhIC RAS (Левый фланг Кавказской линии (Терская область). Каспийский регион (Дагестанская область) и Лезгинская кордонная линия// Фонд старой книги ИИАЭ ДФИЦ РАН).

${ }^{4}$ The history of the Terek Cossacks. URL: http://cossackinozemcevo.ru/ history_terskogo_cossacks (История терского казачества).

${ }^{5}$ Oriental literature. Description of the Grebensky Cossacks of the $18^{\text {th }}$ century. (URL: http://www.vostlit.info/Texts/Dokumenty/Kavkaz/XVIII/1720-1740/ Opis_grebenskich_kazakov/text.htm). (Восточная литература. Описание гребенского казачества XVIII века).

${ }^{6}$ Oriental literature. Description of the Grebensky Cossacks of the $18^{\text {th }}$ Century. URL: http://www.vostlit.info/Texts/Dokumenty/Kavkaz/XVIII/1720-1740/ Opis_grebenskich_kazakov/text.htm. 
${ }^{7}$ The Complete Collection of Laws of the Russian Empire: First Collection: From 1649 to December 12, 1825. SPb.: A type. II Separation of property. E.I.V. Chancellery, 1830. 48 vol.: Decree. T. 38. 3. 568. (Полное Собрание Законов Российской Империи: Собрание первое: С 1649 по 12 декабря 1825 года. СПб.: Тип. ІІ Отд-ния собств. Е. И. В. канцелярии, 1830. 48 т.: указ. Т. 38).

\section{REFERENCES}

Barrett, T. M. 2000. The Uncertainty Line of the North Caucasian 'Frontier' of Russia. In American Russian Studies: The Historical Landmarks of Historiography of the Recent Time. The Imperial Period. Samara: Samara University Press. Original in Russian (Барретт Т. М. Линии неопределенности: северокавказский «фронтир» России // Американская русистика. Вехи историографии последних лет. Имперский период: Антология. - Самара: Изд-во «Самарский университет». С. 163-195).

Bulatov, B. B., Bolokhina, N. I. 2010. The Terek Cossacks (Stages of Russia's Colonization of the Lands of the North Caucasus). Makhachkala: DGU. Original in Russian (Булатов Б. Б., Болохина Н. И. Терское казачество (этапь колонизации Россией земель Северного Кавказа). Махачкала: ДГУ).

Fyodorov, V. A. (ed.) 1991. Notes of A. P. Ermolova 1798-1826. Moscow: Vysshaya Shkola. Original in Russian (Записки A. П. Ермолова. 1798-1826 г2. / Сост. В. А. Федорова. М.: Высшая школа).

Garunova, N. N. 2008. The Administrative and Cultural Role of Fortified Cities in Russian Politics in the North-East Caucasus in the $18^{\text {th }}-$ first half of the $19^{\text {th }}$ Centuries. Makhachkala: Raguga-1. Original in Russian (Гарунова Н. Н. Административная и культурная роль городовкрепостей в политике России на Северо-Восточном Кавказе в XVIII первой половине XIX вв. Махачкала: Радуга-1).

Khodarkovsky, M. 2019. Russia's Steppe Frontier: The Formation of a Colonial Empire, 1500-1800. Moscow: Novoe literaturnoe obozrenie. Original in Russian (Ходарковский М., Степнье рубежи России. Как создавалась колониальная империя 1500-1800. М.: Новое литературное обозрение).

Kiryukhin, V. S. 2000. Reflection of Modern History, Ethnic Ties and National Relations in Russian Folklore in the North Caucasus, as well as in the Don, Caspian, and Yaik in Interaction. Saratov. Original in Russian (Кирюхин В. С. Отражение новейшей истории, этнических связей и национальных отношений в русском фольклоре на Северном Кавказе, а также на Дону, Каспии, Яике во взаимодействии. Саратов: б.и.).

Lebedeva, N. M. 1991. Psychological Aspects of Ethnic Ecology. In Kozlov, V. I. (ed.), Ethnic Ecology: Theory and Practice. Moscow: Nauka. Original in Russian (Лебедева Н. М. Психологические аспекты этнической эколо- 
гии // Этническая экология: теория и практика // Отв. ред. В. И. Козлов. М.: Наука).

Luguev, S. A., Mansurov, M. Kh. 2002. Russians. In Arutyunov, S. A. et al. (eds.), Peoples of Dagestan. Moscow: Nauka. Original in Russian (Лугуев С. А., Мансуров М. Х. Русские. Народы Дагестана // Отв. ред. Арутюнов С. А. и др. М.: Наука).

Maksimov, E. 1890. The Terek Cossack Army. In Terek Collection. Issue 1. Vladikavkaz. Original in Russian (Максимов Е. Терское казачье войско // Терский сборник. Вып. 1. Владикавказ).

Materials for statistics of the Kizlyar regiment of the Terek Cossack army 1858-1868. From the fund of the old and rare book of the Dagestan Federal Research Center of the Russian Academy of Sciences. Original in Russian (Материалы для статистики Кизлярского полка Терского казачьего войска 1858-1868 гг.) / Из фонда старой и редкой книги Дагестанского федерального исследовательского центра РАН).

Mutieva, O. S. 2006. The Role of a Cossack Woman in the Life of the Population of the Nizhny Terek in the $19^{\text {th }}-$ Early $20^{\text {th }}$ Centuries. Makhachkala: Dagestan State University. Original in Russian (Мутиева О. С. Роль женшины-казачки в жизни населения Нижнего Терека в XIX-начале $X X$ вв. Махачкала: ДГУ).

Nomikosov, S. 1884. Statistical Description of the Area of the Don Army. Novocherkassk: Regional Don Printing Office. Original in Russian (Hoмикосов С. Статистическое описание области войска Донского. Новочеркасск: Областная Войска Донского типография).

Omelchenko, I. L. 1991. Terek Cossacks. Vladikavkaz. Original in Russian (Омельченко И. Л. Терские казаки. Владикавказ).

Pallas, P. S. 1974. Notes on Travels to the Southern Governorships of the Russian State in 1793 and 1794. In Gardanov, V. K. (ed.), Adygs, Balkars and Karachais in the news of European authors of the $13^{\text {th }}-19^{\text {th }}$ Centuries. Nalchik: Elbrus. Original in Russian (Паллас П. С. Записки о поездках в южные губернии Российского государства в 1793 и 1794 гг. Адыги, балкариьь и карачаевиь в новостях европейских авторов XIII-XIX вв. // Сост. В. К. Гарданов. Нальчик: Эльбрус).

Panarin, S. 1999. Russian-Speaking at the External Borders of Russia: Answers and Challenges. Diasporas, No. 2-3. Original in Russian (Панарин C. Русскоязычные на внешних границах России: ответы и вызовы. Диаспоры, № 2-3).

Pylkov, O. S. 2011. The Russian Army in the Transformative Process in the North Caucasus (the late $18^{\text {th }}$ - first half of the 19th Centuries. Armavir Original in Russian (Пылков О. С. Российская армия в трансформа- 
ционных прочессах на Северном Кавказе (конеи XVIII - первая половина XIX вв.). Армавир).

Popko, I. D. 1880. The Terek Cossacks from Ancient Times. SPb., Iss. 1. Original in Russian (Попко И. Д. Терское казачество с древнейших времен. СПб., Вып. 1.)

Potto, V. A. 1885. The Caucasian War in Essays, Episodes, Legends and Biographies. SPb.: Type. R. Golike, V. I. Original in Russian (Потто B. A. Кавказская война в отдельных очерках, эпизодах, легендах и биографиях. СПб.: Тип. Р. Голике).

Ryblova, M. A. 2009. The Male Communities of the Don Cossacks as a Sociocultural Phenomenon of the $16^{\text {th }}$ - first third of the $19^{\text {th }}$ century. Outlines of the Doctorate thesis. Volgograd. Original in Russian (Рыблова М. А. Мужские сообщества донских казаков как социокультурный феномен XVI- первой трети XIX в. Автореф. Докт. Диссертации. Волгоград).

Savchenko, D. I. 1999. Terek Cossack East 425 years of Seniority. Pyatigorsk: Publishing house of the Perm State Technical University. Original in Russian (Савченко Д. И. Терское казачье восток 425 лет стариинства. Пятигорск: Изд-во ПГТУ.)

Selimov, A. K. 1964. Terms of the Turkic Origin Denoting Tools and Cattle Breeding in the Dialect of the Village of Aleksandrovskaya, Kizlyar region of the DASSR. Academic Bulletin. Vol. 12. Philological series. Makhachkala (pp. 91-103). Makhachkala. Original in Russian (Селимов А. К. Термины орудий труда и животноводства тюрского происхождения в говоре станицы Александровской Кизлярского района ДАССР // Ученые записки. Т. ХІІ. Серия филологическая. Махачкала. С.: 91-103).

Shidlovsky, Y. 1843. Notes about Kizlyar. Journal of the Ministry of Internal Affairs for 1843. Part 4. №. 1-12. (Шидловский Ю. Записки о Кизляре. Журнал Министерства Внутренних дел за 1843 год. Ч. 4. № 1-12).

Shcherbina, F. A. 1910. History of the Kuban Cossack Army. Vol. 1. Ekaterinodar: Printing House of the Kuban regional government. Original in Russian (Щербина Ф. А. История кубанского казачьего войска. Т. 1. Екатеринодар: Тип. Кубанского областного правления).

Shcherbina, F. A. 1992. History of the Kuban Cossack Army. 2 vols. Krasnodar (Reprint. Ekaterinodar, 1910-1913). Vol. 1. Original in Russian (Щербина Ф. А. История кубанского казачьего войска. Екатеринодар: Тип. Кубанского областного правления, 1910. Т. 1. (Репринт. Екатеринодар, 1910-1913). Выпуск 1).

Tsibulnikova, A. A. 2008. The Role of Women in the Processes of Peaceful Interaction between the Cossacks and the Highlanders of the North Caucasus in the $18^{\text {th }}-19^{\text {th }}$ Century. Kuban Cossack army. In Cossacks and Peoples of Russia: The Ways of Cooperation and Service in Russia. Mate- 
rials of the correspondence scientific-practical conference. Krasnodar: Kuban State Univeristy. URL: http://slavakubani.ru/geography/neighbors/ traditions-neighborliness/rol-zhenshchin-v-protsessakh-mirnogo-vzaimodeystviya-kazakov-i-gortsev-severnogo-kavkaza-v-khviii-xi/. Original in Russian (Цибульникова А. А. Роль женщин в процессах мирного взаимодействия казаков и горцев Северного Кавказа в XVIII-XIX вв. Кубанское казачье войско / Казачество и народы России: пути сотрудничества и служба России: материаль заочной научно-практической конференции. Краснодар: Кубанский государственный университет).

Statistical monograph on the study of the village life of the Terek Cossack army. 1881. Vladikavkaz: Vladikavkaz, Troops of economic management. Original in Russian (Статистическая монография по исследованию станичного быта терского казачьего войска. Владикавказ: Владикавказ, Войсковое хоз. правл.).

Turner, F. J. 2009. The Frontier in American History. M.: Ves mir. Original in Russian (Тёрнер Ф. Фронтир в американской истории. М.: Весь мир).

Tkachev, G. A. 1911. Grebensky, Tersky and Kizlyar Cossacks. A book to read in the Villages and Regimental Schools, Libraries and Teams. Vladikavkaz: Electric furnace printing house of the Tersk Regional Board. Original in Russian (Ткачев Г. А. Гребенские, Терские и Кизлярские казаки. Книга для чтения в станицах и полковых школах, библиотеках и командах. Владикавказ: Электропечная типография Терского Областного Правления).

Tkachev, G. A. 1912. Chervlennaya Village. In Collection of the Society of Lovers of Cossack Antiquity. No. 12. Vladikavkaz. (Ткачев Г. А. Станица Червленная // Сборник общества любителей казачьей старины. № 7-12. Вып. 1. Владикавказ).

Tolstoy, L. N. 1963. Cossacks. The Caucasian Tale of 1852. Moscow. Original in Russian (Толстой Л. Н. Казаки. Кавказская повесть 1852 года. М.).

Vasiliev, D. S. 1986. Essays on the History of the Lower Reaches of the Terek. Makhachkala: Dagestan Book Publishing House. Original in Russian (Васильев Д. С. Очерки истории низовьев Терека. Махачкала: Дагестанское книжное издательство).

Velikaya, E. V. 2012a. Measures of the Russian Government to Develop Trade in the North-East Caucasus in the first half of the $19^{\text {th }}$ Century. Historical, philosophical, political and legal sciences, cultural studies and art history. Questions of Theory and Practice. Tambov: Diploma, No. 9 (23). In 2 vols. Vol. I. Original in Russian (Великая Е. В. Меры правительства России по развитию торговли на Северо-Восточном Кавказе в первой половине XIX в. // Исторические, философские, политические и юридиче- 
ские науки, культурология и история искусства. Вопросы теории и практики. Тамбов: Диплом № 9 (23): в 2 ч. Часть I).

Velikaya, E. V. 2012b. The Evolution of Trade Relations in the North-East Caucasus in the First Half of the $19^{\text {th }}$ Century. In Regional SocioHumanitarian Research. History and Modernity: Materials of the International Scientific and Practical Conference on January 25-26, 2012. Penza: Sotsiosfera. URL: http://sociosphera.com/publication/conference/ 2012/158/evolyuciya_torgovyh_otnoshenij_na_severovostochnom_kavka ze_v_pervoj_polovine_xix_veka/. Original in Russian (Великая, Е. В. Эволюция торговых отношений на Северо-Восточном Кавказе в первой половине XIX века. // Региональные соичогуманитарные исследования. История и современность: материаль международной научно-практической конференции 25-26 января 2012 года. Пенза; Прага; Семей: Научно-издательский центр «Социосфера». С. 46-48).

Velikaya, N. N. 2004. Trepak and lezginka. Where did the Greben Cossacks Come from. Rodina 5. Original in Russian (Великая Н. Н. Трепак и лезгинка. Откуда произошли казаки-гребенцы. Родина 5).

Vinnikov, N. P. 1897. A Brief Historical Outline of the Terek Cossack Army and the Cities of the Terek region. In Notes of the Caucasus Department of the Imperial Russian Geographical Society. Book 19. (Винников Н. П. Краткий исторический очерк Терского казачьего войска и городов Терской области // Записки Кавказского отдела императорского русского географического общества. Книжка XIX).

Webb, W. P. 1964. The Great Frontier. Austin: University of Texas Press.

Zubov, P. P. 1833. A Picture of the Caucasus Region Belonging to Russia and its Adjacent Lands in Historical, Statistical, Ethnographic, Financial and Commercial Relations. In 4 vols. St. Petersburg: Konrad Wingeber Printing House, Vol. 2 (Зубов П. П. Картина Кавказского края, принадлежамего России и сопредельных оному земель в историческом, статистическом, этнографическом, финансовом и торговом отношениях. В 4-х частях. СПб.: Типография Конрада Вингебера, Т. II).

\section{Archives}

Archive of SONIA, fund prof. Kokiev. O. 1, D. 203. (Архив СОНИИ, фонд проф. Кокиева.)

Central State Archives of the Republic of Dagestan Fund. 374. Inventory. 1. Business. 137. (Центральный государственный архив Республики Дагестан. Фонд 374, Опись 1, Дело 137.)

Central State Archives of the Republic of Dagestan. Fund. 379. Inventory. 5. Case 86. (Центральный государственный архив Республики Дагестан. Фонд 379, Опись 5, Дело 86.) 